Ks. Wojciech Węgrzyniak

Verbum Vitae

28 (2015) 59-89

\title{
TRZY INTRYGUJACCE ASPEKTY ŚWIADECTWA W PSALMACH
}

\section{Three Intriguing Aspects of Testimony in Psalms}

\begin{abstract}
The aim of this article is to analyze three difficult aspects of testimony in the Book of Psalms: (1) the term $\varsigma_{e} d \hat{u} t$ in the titles of certain Psalms (Ps 60:1; 80:1); (2) understanding who or what is referred to as a witness in Ps 89:38;

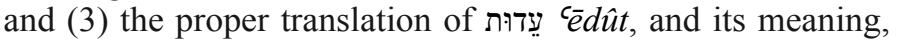
in its multiple uses in Ps 119. First, as background, the author synthetically depicts what the psalms say generally regarding the notion of testimony. Proceeding to the focal issues, he first analyzes עִ עִדוּר that the term should be interpreted as an independent title and translated as "testimony". The next section presents the current understandings of who or what is a witness in Ps 89:38 (rainbow, sun, moon, throne, God), and proposes a new messianic interpretation. In the final part, after the presentation of various

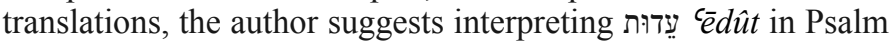
119 as a technical term, properly translated in Psalm 119 always as "testimony".
\end{abstract}

Keywords: testimony, witness, translation, title, psalms, Ps 60, Ps 80, Ps 89, Ps 119

Streszczenie: Celem artykułu jest analiza trzech dyskusyjnych

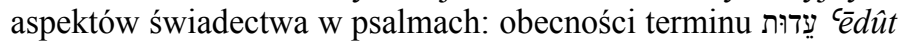
w tytułach psalmów (Ps 60,1; 80,1), rozumienia, kim jest świa- 
dek w Ps 89,38 oraz thumaczenia terminu עֵּוּר Cédût w Ps 119. Najpierw autor syntetycznie prezentuje to, co Psalmy mówią na temat świadectwa (pkt 1). Następnie zajmuje się analizą terminu

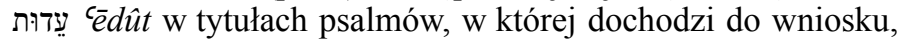
iż termin ten należy interpretować jako niezależną część tytułu i tłumaczyć jako, ,świadectwo" (pkt 2). W kolejnej części przedstawia dotychczasowe propozycje egzegetów rozumienia, kim jest świadek w Ps 89,38 (tęcza, słońce, księżyc, tron, Bóg) oraz proponuje nową interpretację mesjańską (pkt 3). W ostatniej części, po prezentacji stanu tłumaczeń, proponuje interpretację

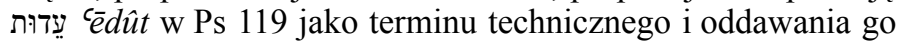
zawsze terminem ,świadectwo".

Słowa kluczowe: świadectwo, świadek, thumaczenie, tytuł, psalmy, Ps 60, Ps 80, Ps 89, Ps 119.

Celem niniejszego artykułu jest analiza trzech dyskusyjnych aspektów świadectwa w psalmach: obecności

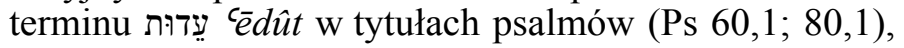
rozumienia, kim jest świadek w Ps 89,38 , oraz tłumaczenia

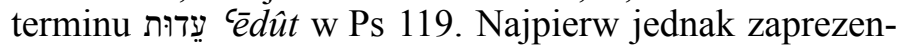
tujemy syntetycznie to, co Psalmy mówią na temat świadectwa.

\section{Statystyka I ZARYS SYNTETYCZNY}

Nie biorąc pod uwagę dyskusyjnych kwestii gramatycznych ${ }^{1}$ i różniących się $\mathrm{w}$ niektórych detalach konkordancji i słowników, statystyka słów zawierających ideę świadectwa przedstawia się następująco²:

${ }^{1}$ Wspomniane dyskusyjne kwestie omawia Volkwein, ,Masoretisches 'edut, 'edwot, 'edot', 18-40.

2 Pod uwagę zostały wzięte: Mandelkern, Veteris Testamenti, 829831; Lisowski, Konkordanz, 1026-1030; Even-Shoshan, Concordance,

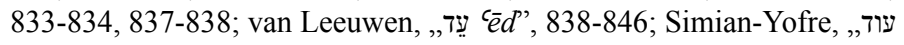
'wd', 483-507; Clines, Dictionary, VI, 271-272, 278, 287-288; BW 10 (CD-ROM). 


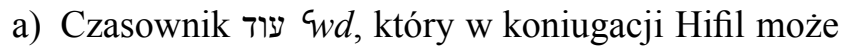
przyjmować znaczenie ,świadczyć”, w TM występuje 39 razy, w tym tylko 2 razy w Psałterzu (Ps 50,7; 81,9) ${ }^{3}$. W obydwu tych miejscach Bóg jawi się jako sędzia, który zamierza świadczyć przeciw swojemu ludowi.

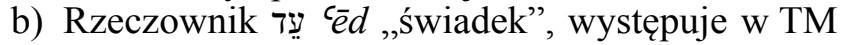
69 razy, w tym w Psalmach użyty jest trzykrotnie, dwa razy mowa jest o świadkach fałszywych, względnie gwałtownych, którzy są wrogami psalmisty (Ps 27,12; 35,11), raz mowa jest o tajemniczym, ale działającym na korzyść pokolenia Dawida świadku w chmurach (Ps 89,38).

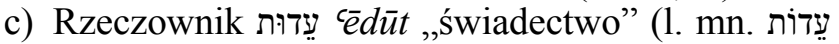
๔èdôt) występują w TM łącznie 83 razy, z czego 34 razy

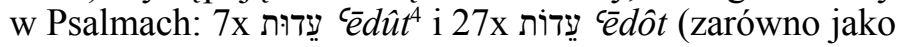
scriptio plena jak i scritpio defectiva ${ }^{5}$ ). Niektórzy rozróżniają rzeczowniki w inny sposób. Wg Mandelkerna

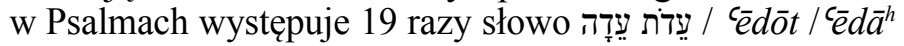
w znaczeniu ,świadectwo, przykazanie Boże” i 15 razy עִ צִדוּר

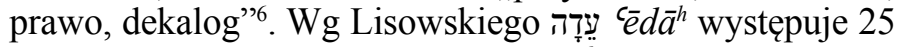

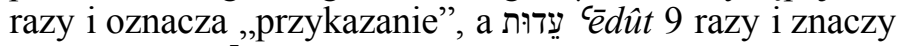
„świadectwo"7. Even-Shoshan wylicza 27 pojawień się

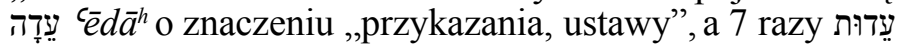

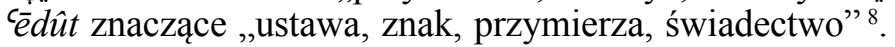

Warto zauważyć, że w samym Ps 119 rzeczownik ten występuje 23 razy, dwa razy znajduje się w tytułach psalmów (Ps 60,1; 80,1) i tylko w jednym z 34 przypadków rzeczownik bezpośrednio nie odnosi się do świadectwa

${ }^{3}$ Jednak G. Lisowski (Konkordanz, 1030) oba użycia w psalmach klasyfikuje do grupy znaczeniowej „ostrzegać, upominać”. Podobnie Clines, Dictionary, 288.

${ }^{4}$ Ps 19,$8 ; 60,1 ; 78,5 ; 80,1 ; 81,6 ; 119,88 ; 122,4$.

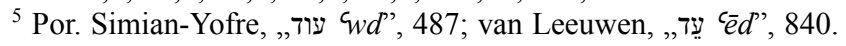
Scriptio plena (8x) znajduje się w Ps 78,56; 119,14.31.36.99.111.129.1 44.157. Scriptio defectiva (19x) obecna jest w Ps 25,10; 93,5; 99,7; 11 9,2.22.24.46.59.79.95.119.125.138.146.152.167.168; 132,12.

${ }^{6}$ Por. Mandelkern, Veteris Testamenti, 830.

${ }^{7}$ Por. Lisowski, Konkordanz, 1028.

${ }^{8}$ Por. Even-Shoshan, Concordance, 833-834. 
Boga (Ps 122,4). We wszystkich pozostałych wersetach psalmista mówi o świadectwie ze strony Boga. To Bóg je dał swojemu ludowi (Ps 78,5; 81,6) i da je również w przyszłości (Ps 132,12). Świadectwo Pana jest sprawiedliwe (Ps 119,138.144) i wierne (godne wiary), uczące mądrości prostego człowieka (Ps 19,8; 93,5). Świadectwa należy strzec (Ps 25,10; 99,7; 119,22.88.95.146.167.168), chociaż nie zawsze ludowi się to udawało (Ps 78,56; zob. Ps 119,157). Strzeżenie świadectwa daje szczęcie (Ps 119,2 ), a samo świadectwo jest radością (Ps 119,14), rozkoszą (Ps 119,24), dziedzictwem (Ps 119,111), cudem (Ps 119,129). Do świadectwa można przylgnąć (Ps 119,31), nakłonić serce (Ps 119,36), mówić o nim wobec królów (Ps 119,46), wracać do nich (Ps 119,59), znać je (Ps 119,79.125.152), rozmyślać o nim (Ps 119,99) i je miłować (Ps 119,119.167).

d) W Psalmach nie występują ani razu słowa עָדָה ๔ē $\bar{a}^{h}$,świadek, świadectwo" (4x w TM) i i „świadectwo" (3x w TM).

$\mathrm{Na}$ podstawie analizy statystycznej dochodzimy do następujących obserwacji:

a) Psalmy są księgą, którą trudno pominąć w opracowaniu starotestamentalnej idei świadectwa. $20 \%$ wszystkich słów w Biblii Hebrajskiej przekazujących ideę świadectwa znajduje się w Psałterzu.

b) W Psalmach świadectwo ma wybitnie teologiczny charakter. Poza nielicznymi wyjątkami, prawie zawsze odnosi się ono do świadectwa, które pochodzi od Boga. Pieśni Izraela koncentrują się przede wszystkim na świadectwie, które Bóg dał swojemu ludowi.

c) Swiadectwo Boga przestawione jest w psalmach zasadniczo jako pozytywny dar, źródło szczęścia i radości. Poza paroma wyjątkami, w których świadectwo Boga przybiera napominający charakter, dla modlącego się Izraelity świadectwo kojarzy się z obiektem miłości i pragnienia, obiektem, którego należy sumiennie strzec.

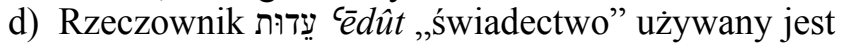
prawie czterokrotnie częściej w liczbie mnogiej niż pojedynczej. Świadectwo widziane było zatem przez autorów 
nie tyle jako idea abstrakcyjna, lecz bardziej jako konkretna i powtarzająca się manifestacja Bożego objawienia9

e) Biorąc pod uwagę różnorodne opinie na temat znaczeń poszczególnych słów związanych z rdzeniem עוד $\mathcal{w} d$, należy mieć świadomość, że w polu semantycznym świadectwa niekiedy przesuwamy się bardziej w kierunku przykazań, napomnień czy ogólnie Słowa Bożego. Nie wydaje się jednak właściwe, by w analizie tematu świadectwa w psalmach ograniczać się tylko do tych miejsc, które powszechnie wiązane są przez egzegetów z ideą świadectwa. Zarówno przykazanie, ustawa, prawo czy Słowo Boże posiadają $\mathrm{w}$ języku hebrajskim swoje odpowiednie słowa.

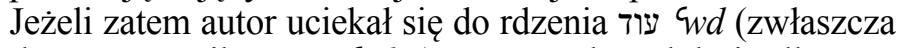
do rzeczownika עֵּוּ że zależało mu, by prawo, ustawy czy nauczanie ukazać ostatecznie jako świadectwo Bożej troski o człowieka ${ }^{10}$.

\section{Termin פִּדוּר}

W tytułach psalmów dwukrotnie występuje słowo

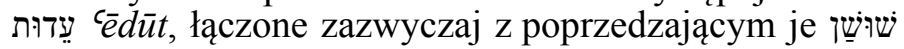
šûšan „lilia" i thumaczone dosłownie „Na lilię świadectwa”

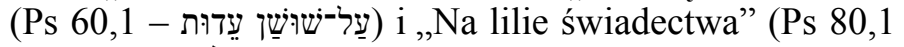
- W obu przypadkach nie udało się ustalić znaczenia tego wyrażenia.

Jeśli chodzi o przekaz tekstualny, tylko jeden manuskrypt hebrajski i to z początku XIV w. (K97) opuszcza

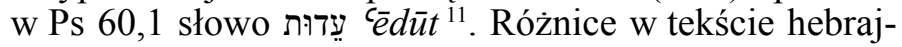
skim są jednak widoczne na poziomie pracy masoretów. W Ps 60,1 za pomocą akcentu łączącego Munah połączyli

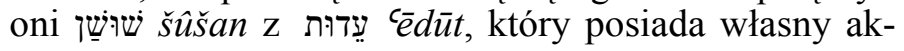

${ }^{9}$ S. Choon-Leong („The Designation”, 194) nazywa takie użycia rzeczownika ,concretization of the covenant".

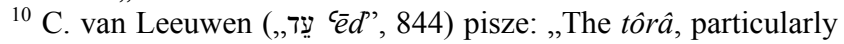
the Decalogue, functioned for Israel as a 'witness' or 'testimony' of God's saving activity (Exod 20:2; cf. Psa 81:7f., 11) and, esp., of his will (Exod 20:3ff.; cf. Psa 81:10)".

${ }^{11}$ Por. Kennicott, Vetus Testamentum, II, 356. 


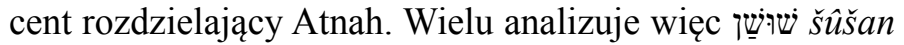
jako status constructus i rozumie całość wyrażenia jako

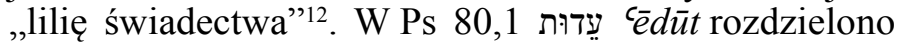

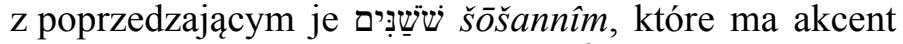

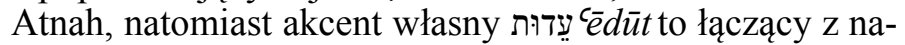
stępnym wyrazem עֵדוּת ¿édūt należało czytać jako status constructus, to trzeba by ten fragment tytułu tłumaczyć jako ,świadectwo Asafa” /,świadectwo dla Asafa". Równie dobrze jednak 'ēdūt można interpretować jako status absolutus. „Swiadectwo" byłoby tytułem samo w sobie.

Wersje greckie oddają tekst hebrajski na kilka sposobów $^{13}$. LXX w Ps 59,1 (TM 60,1) czyta o tych, którzy

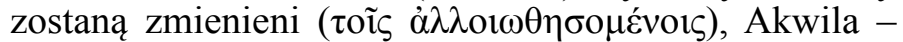

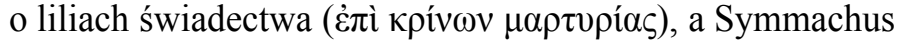

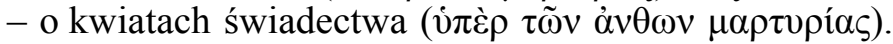
W Ps 79,1 (TM 80,1) LXX zatrzymuje lekcję o tych, co zostaną zmienieni, ale dodaje słowo $\mu \alpha \rho \tau u ́ \rho ı v$, ,świadec-

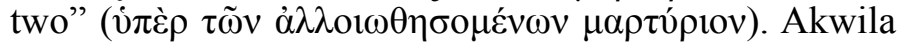
i Symmachus zasadniczo thumaczą jak w Ps 59,1 (Akwila

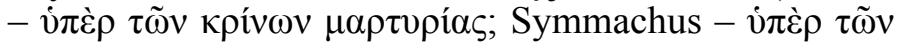

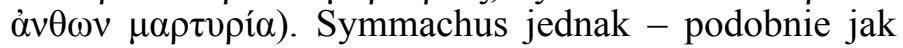
LXX - nie wiąże świadectwa $\mathrm{z}$ poprzedzającym słowem, tylko z następującym, co daje sens ,świadectwo dla Asafa" ( $\mu \alpha \rho \tau u ́ \rho 10 v \tau \tilde{\omega}$ A $\sigma \alpha \varphi-\mathrm{LXX}$ i $\mu \alpha \rho \tau v \rho i ́ \alpha \tau \tilde{\omega}$ A $\sigma \alpha \varphi-$ Symmachus).

Przekłady łacińskie idą zasadniczo za wersjami grecki$\mathrm{mi}^{14}$. W Ps 59,1 (TM 60,1) Vetus Latina i Wulgata mówią o tych, co się zmienią (his qui inmutabuntur), natomiast Iuxta Hebraeos Hieronima thumaczy ,Dla lilii. Świadectwo" (pro liliis testimonium). W Ps 79,1 (TM 80,1) Vulga-

${ }^{12}$ Jednak J. Goldingay (Psalms, II, 224) zauważa słusznie, że šûšan może być tutaj w status absolutus, zwracając uwagę na to, że w pozostałych przypadkach to słowo użyte jest w 1 . mn. i zawsze jako status absolutus. Możliwość takiej lektury widzi także Delitzsch, Psalms, II, 77.

${ }^{13}$ Por. Field, Origenis hexaplorum, II, 188, 231; Rahlfs, Psalmi, 177, 220; Staerk, „Zur Kritik”, 113-114, 120.

${ }^{14}$ Por. Boese, Anonymi Glossa, I, 248. 358; De Sainte-Marie, Sancti Hieronymi psalterium, 85. 116. 
ta ma: „Dla tych, którzy zostaną zmienieni. Świadectwo” (pro his qui commutabuntur testimonium), Vetus Latina: „Dla tych, którzy zostaną zmienieni. Świadectwa” (pro his qui commutabuntur testimonia), natomiast Hieronim w Iuxta Hebraeos thumaczy „Dla lilii świadectwa” (pro liliis testimonii).

Targum w Ps 60,1 mówi o starym świadectwie (על עתיק סהדותא), które miało miejsce między Jakubem a Labanem ${ }^{15}$. Natomiast w Ps 80,1 tytuł wspomina zasiadających w Sanhedrynie, którzy się zajmują świadectwem prawa (על יתבי סנהדרין די מתעסקין בסהדות).

Przegląd wersji antycznych prowadzi do kilku wnios-

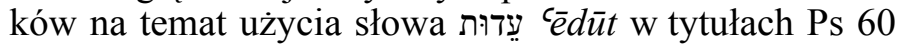
i 80 :

a) Słowo to jest thumaczone jako świadectwo albo jest opuszczane.

b) Świadectwo występuje zarówno w liczbie pojedynczej, jak i mnogiej.

c) Świadectwo łączy się ze słowem poprzedzającym (lilia świadectwa), następującym (świadectwo Asafa) albo występuje całkowicie niezależnie (świadectwo). $Z$ tego wynika, że zarówno ze strony morfologicznej, jak i zastosowania akcentów hebrajskich nie można twierdzić, że świadectwo należy łączyć w obu tytułach Ps 60 i 80 z kwiatem lilii.

Bez względu na to, czy עִדּוּת cédūt w Ps 60,1 i 80,1 połączymy ze słowem poprzedzającym czy następującym, pozostaje pytanie, co ten tytuł może w ogóle oznaczać? Historia egzegezy zaproponowała wiele rozwiązań, które można by podzielić na następujące:

a) Rodzaj instrumentu muzycznego - chodziłoby o instrument muzyczny, na którym psalm miał być wykonywany. Ibn Ezra w komentarzu do Ps 80 twierdzi, że עִדוּת

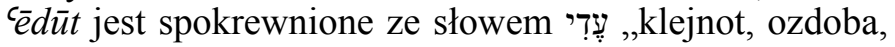

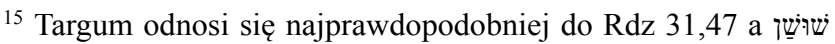
- šûšān wyprowadza od słowa יָשָָׁ, ,stary”, por. Stec, The Targum of Psalms, 119.

${ }^{16}$ Por. Stec, The Targum of Psalms, 156. 
ornament" i opisuje piękno instrumentu ${ }^{17}$. Meiri i Mecuda Syjon podzielają opinię, że instrument ten wydaje piękny dźwięk, stąd podobny jest on do róży, najbardziej ulubionego kwiatu ${ }^{18}$. Me'am Lo'ez mówi o bardzo imponującym instrumencie ${ }^{19}$. Ponadto Meiri w komentarzu do Ps 80,1 mówi o pewnej ustalonej roli dla tego instrumentu w czasie wykonywania psalmu ${ }^{20}$.

b) Klejnot - albo psalm jest rzadkim klejnotem wśród psalmów (Ibn Ezra dla Ps 8021), albo psalm ten był klejnotem, ozdobą Asafa (Me'am Lo'ez) ${ }^{22}$.

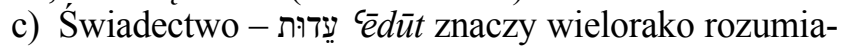
ne świadectwo. W komentarzu do Ps 60 Raszi twierdzi, że to aluzja do Wielkiego Sanhedrynu, który przyjmuje świadectwo i ma ostateczną władzę jurysdykcyjną 23. Natomiast Ps $80 \mathrm{wg}$ niego daje świadectwo o trzech nieszczęśliwych okresach w historii, kiedy Żydzi cierpieli na wygnaniu ${ }^{24}$. Hirsch mówi o róży świadectwa i tłumaczy, że różą jest Izrael, który może przeżyć i kwitnąć tylko wtedy, kiedy jest zakorzeniony w świadectwie o Bożym Prawie ${ }^{25}$. Natomiast w komentarzu do Ps 80 zauważa, że dwa słowa (róża i świadectwo) są rozdzielone. Zatem ‘èdūt wska-

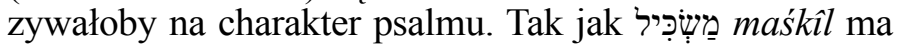
określać, że psalm służy do pouczania, tak 'édūt wskazywałby, że psalm ma służyć jako świadectwo. Świadectwo zawarte w psalmie, które ma być dane ludowi, znajduje się przede wszystkim w w. 9-20 i stanowi główny temat psalmu. Świadectwo o pochodzeniu Izraela i dawnych czasach ma być świadectwem pewności ostatecznego wybawienia ${ }^{26}$. Wg anonimowego komentatora ${ }^{c} \bar{e} \bar{u} t$ oznacza świadectwo

${ }^{17}$ Por. Feuer, Tehillim, 746.

${ }^{18}$ Por. Neubauer, „The Authorship”, 50-51; Feuer, Tehillim, 746.

${ }^{19}$ Por. Yalkut Me'am Lo'ez, Torah Anthology, II, 369.

${ }^{20}$ Por. Neubauer, „The Authorship”, 53.

${ }^{21}$ Por. Feuer, Tehillim, 1014.

${ }^{22}$ Por. Yalkut Me'am Lo'ez, Torah Anthology, III, 309.

${ }^{23}$ Por. Feuer, Tehillim, 746.

${ }^{24}$ Por. Feuer, Tehillim, 1014.

${ }^{25}$ Por. Hirsch, The Psalms, I, 409-410.

${ }^{26}$ Por. Hirsch, The Psalms, II, 74-75. 
Sanhedrynu, który podobny jest do lilii ${ }^{27}$. Natomiast Briggs twierdzi, że tytuł w pierwszym znaczeniu wskazywał na pochwałę Pana: „moje świadectwo jest jak piękny zawilec”28.

d) Określenie pieśni na Święto Tygodni - psalmy te śpiewane były z okazji Święta Tygodni (Pięćdziesiątnicy), kojarzonego ze świadectwem. Wtedy to bowiem wspominano rocznicę nadania Bożego Prawa na Synaju. Słowo עִדּוּת przymierza $^{29}$.

e) Przymierze - chodzi nie tyle o świadectwo, ile o przymierze. Kontekst Ps 60 i 80 wskazuje, że ${ }^{\top} d \bar{u} t$ oznacza pieśń odnoszącą się do starego przymierza Jahwe ze wszystkimi pokoleniami Izraela $\left(\right.$ Eerdmans $\left.^{30}\right)$.

f) Lilie kultyczne - Mowinckel twierdzi, że chodzi tutaj o psalmy śpiewane przy okazji boskich wyroczni, w których używano lilii, albo w celu rozpoznania Bożego objawienia, albo jako podziękowanie za nie ${ }^{31}$.

g) Wskazówka melodii - na tę melodię psalm miałby być wykonywany. „Lilia świadectwa” byłaby więc tytułem znanej psalmistom pieśni (Delitzsch ${ }^{32}$, Kraus ${ }^{33}$, Goldingay $^{34}$ i większość współczesnych egzegetów $\left.{ }^{35}\right)$.

${ }^{27}$ Por. Neubauer, „The Authorship”, 51.

${ }^{28}$ L. mn. šōšannîm autor thumaczy jako pluralis intensywności, por. Briggs - Briggs, Psalms, I, LXXV.

${ }^{29}$ Por. William, The Title of the Psalms, 44-47.

${ }^{30}$ Por. Eerdmans, The Hebrew Book of Psalms, 67.

${ }^{31}$ Mowinckel, Psalmenstudien, IV, 29-33. Autor powołuje się na teksty z Lb 17,21-26; Kpł 23,40; Ps 118,27.

32 Autor (Psalms, II, 77) stwierdza: „There must therefore have been some well-known popular song, which began with the words "A lily is the testimony» or "Lilies are the testimonies (עדות)》 and the Psalm is composed and intended to be sung after the melody of this song in praise of the Tôra".

${ }^{33}$ Por. Kraus, Psalmen, I, XXVIII.

${ }^{34} \mathrm{~J}$. Goldingay (Psalms, II, 531, 697, 701) zwraca uwagę na to, że chociaż etymologicznie mowa jest o świadectwie, jakie dał Bóg, to w potocznym języku odnosi się do deklaracji Boga, która wyraża oczekiwania narodu. To jednak nie tyczy się tytułów psalmów, gdzie słowo to może być częścią tytułu melodii.

${ }^{35} \mathrm{~Np}$. Tate, Psalms 51-100, 100; Vesco, Le psautier, I, 533. 
h) Odrębna typologia psalmów - na melodię wskazuje słowo lilia/lilie, natomiast świadectwo jest tylko pewną niezależną informacją, nową typologią psalmów (Zenger ${ }^{36}$, Ravasi $^{37}$ ).

i) Próba uzgodnienia TM z LXX - Delekat próbuje

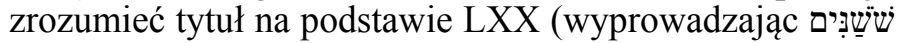
Šsōsannîm z שנים + שנה niać") i widzi w nim albo zachętę do powtórzenia modlitwy (psalm, który należy powtarzać), albo mowę o tych, co się zmienili na gorsze ${ }^{38}$.

i) Z innych propozycji warto wspomnieć niektóre opinie tradycji żydowskiej. Salmon ben Yeroham twierdzi, że tytuł odnosi się do ludzi, którzy zachowują przykazania ${ }^{39}$. Jefte ben Eli mówi, że 'édūt odnosi się do próby, która

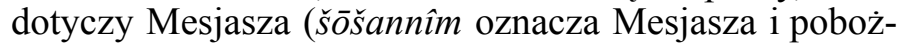
nych ludzi, którzy są jak lilie). Mesjaszem może być też Zorobabel albo sam Dawid. Saadja Gaon uważa, że to rodzaj pieśni Dawida, którą Lewici wysławiali na melodię Szuszan, a celem tej pieśni byłoby sprawienie, by ludzie poznali pomoc Bożą. Natomiast Kimchi twierdzi, że znaczenie tego wyrażenia jest po prostu nieznane ${ }^{40}$.

Do wyżej wymienionych opinii warto dodać przykłady tłumaczeń we współczesnych komentarzach do psalmów. Można je podzielić na następujące kategorie:

a) Autorzy nie tłumaczą wyrażenia, tylko je transliterują, np. Gunkel (eine 'eduth' (Ps 60); eine 'eduth' Asaphs $(\text { Ps } 80)^{41}$.

b) Świadectwo traktowane jest jako niezależna część tytułu w obu psalmach, np. Kraus (Ps 60: Nach „Lilie” $\{?\}$. Ein Zeugnis; Ps 80: 'Nach' „Lilien” (?) Ein Zeugnis); Deissler (Ps 60: Nach „Lilien”. Zeugnis; Ps 80: Nach Lili-

${ }^{36}$ Por. Hossfeld - Zenger, Psalmen 51-100, 459.

${ }^{37}$ Por. Ravasi, Il libro dei Salmi, II, 217-218.

${ }^{38}$ Por. Delekat, „Probleme der Psalmenüberschriften”, 294-295. O zmianie na lepsze lub gorsze pisali również Ojcowie Kościoła, którzy komentowali psalmy, bazując na tłumaczeniu greckim czy łacińskim.

${ }^{39}$ Por. Neubauer, „The Authorship”, 50-51.

${ }^{40}$ Por. Neubauer, ,The Authorship”, 53.

${ }^{41}$ Por. Gunkel, Die Psalmen, 255, 231. 
en. Ein Zeugnis); Seybold (Ps 60: „Auf Lotus”. Ein Zeignis; Ps 80: „Zu Lotusblüten”. Ein Zeugnis von Asaph); Weiser (Ps 60: Nach „Lilie”. Zeugnis; Ps 80: Nach „Lilien”. Zeugnis); Zenger (Ps 60: Nach der Weise „Lotusblüte”. Ein Zeugnis; Ps 80: Nach der Weise „Lotusblüten”. Ein Zeugnis); Ravasi (Ps 60: Su „Gilio”. Comandamento; Ps 80: Su „I gigli”. Precetto); Dahood (Ps 60: According to „Lilies”. A solemn commandment; Ps 80: According to „Lilies”. A solemn commandment).

c) Świadectwo łączone jest z liliami w Ps 60, natomiast w Ps 80 interpretowane jest rozdzielnie, np. Brueggemann (Ps 60: According to the lily of the covenant; Ps 80: On lilies. A covenant); Ross (Ps 60: Set to „The Lily of the Testimony"; Ps 80: Set to „the Lilies”. A Testimony); Lorenzin (Ps 60: Su ,il giglio della testimonianza"; Ps 80: Su ,i gigli”. Testimonianza); Piacentini (Ps 60: Su „il giglio della testimonianza”; Ps 80: Su „i gigli”. Testimonianza di Asaf).

d) Świadectwo łączone jest z lilią/liliami w obydwu psalmach, np. Jacquet (Ps 60: Sur „Les lys du témoignage”; Ps 80: Sur „Les lys les préceptes”); Sabourin (Ps 60: „Sur le lys du témoignage”; Ps 80: „Sur les lis du témoignage”); Lancelotti (Ps 60: Secodno „I gigli del testimonio"; Ps 80: Su ,il gigli della testimonianza").

e) Niektórzy komentatorzy nie zajmują się ani znaczeniem tytułu, ani jego tłumaczeniem, np. Alonso Schökel ${ }^{42}$.

$\mathrm{Na}$ podstawie przedstawionych powyżej danych na temat interpretacji słowa עִ עִּוּת dojść przynajmniej do dwóch następujących wniosków:

a) Nadal otwartą sprawą jest czy 'édūt należy interpretować jako niezależną część tytułu psalmu, czy raczej jako związaną bądź z poprzedzającym, bądź następującym po niej słowem. Biorąc jednak pod uwagę fakt, że wyrażenie bez towarzyszącego mu słowa ${ }^{\complement} \bar{d} \bar{u} t$, jak i to, że masoreci nie byli konsekwentni w łączeniu świadectwa z poprzedzającym je kwiatem lilii, a ponadto uwzględniając w tym

${ }^{42}$ Por. Alonso Schökel - Carniti, I Salmi, I. 
aspekcie wersje antyczne, wydaje się bardzo prawdopodobne, że ‘édūt jest niezależną częścią tytułu psalmów 60 i 80.

b) $\mathrm{Z}$ powyższych racji nie ma potrzeby intepretowania $\varsigma_{e} d \bar{u} t$ w kluczu instrumentu muzycznego czy jakiejś melodii. W tłumaczeniach należy zostawić słowo „świadectwo", a w treści Ps 60 i 80 szukać odpowiedzi na pytanie, o jaki rodzaj świadectwa chodzi. Ps 60, przypominając o zwycięstwie Dawida nad Aramem i Joaba nad Edomem, służy jako świadectwo zwycięstwa Izraela nad wrogami. Śpiewając ten psalm, Izrael przypomina sobie o tym, że może zwyciężyć i przypomina Bogu o tym, że zwyciężyć powinien. Natomiast w Ps 80 świadectwem jest historia zbawienia, w której Bóg wyprowadził swój naród z Egiptu i osadził w Ziemi Obiecanej. To świadectwo ma dodać nadziei przygnębionemu zburzeniem Jerozolimy ludowi i przyspieszyć pomoc Boga, który nie po to uwolnił lud swój od Egipcjan, by pozwolić na niewolę w krainie Babilonii.

\section{3. Ś WiadeK w Ps 89,38}

Jednym z najbardziej dyskusyjnych elementów świa-

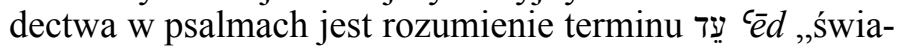
dek" w Ps 89,38. Słowo to występuje w kontekście obietnicy wiecznego i nierozerwalnego przymierza, które Bóg dał Dawidowi i jego potomstwu (w. 4-5; 29-31). Po zapewnieniu, że przymierze to nie może zostać złamane nawet przez niewierność ludu (w. 31-35), Bóg mówi:

Raz przysiągłem na moją świętość:

na pewno nie skłamię Dawidowi.

Potomstwo jego trwać będzie wiecznie

i tron jego będzie przede Mną jak słońce, jak księżyc, co pozostaje na wieki,

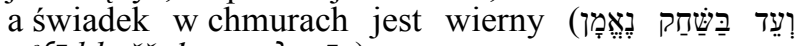
$w^{e} \complement_{\bar{e}} d$ baššahaq ne'emān).

(w. 36-38

${ }^{43}$ Również Tate sugeruje, by łączyć w. $38 \mathrm{z}$ ww. 36-37, a nie tylko z w. 37, jak proponuje Veijola, por. Tate, Psalms, 425; Veijola, Verheissung in der Krise, 33-34. 
Zmierzając się z próbą zrozumienia $\Upsilon^{e} d \mathrm{w}$ Ps 89,38 , warto zwrócić uwagę na następujące kwestie.

\subsection{Sytuacja tekstualna}

Wszystkie manuskrypty hebrajskie przekazują w Ps 89,38 zgodnie עִ עֵד wokalizowane jako. Raczej nie może być wątpliwości, że chodzi o świadka. Tylko Ms K 133 nie tyle umieszcza świadka $\mathrm{w}$ chmurze, ile porównuje בשחק go do chmury, czytając כשחק „W chmurze”. Lekcję tę należy thumaczyć jako dość powszechny błąd kopisty, polegający na zamianie ב כ כ כ

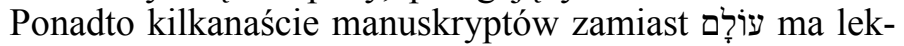
cję לִ לִ co jednak nie zmienia sensu pierwszej części w. $38^{44}$.

LXX podaje, że ,świadek w niebie [jest] wierny"

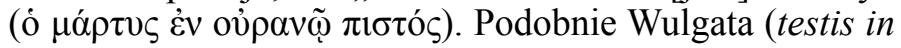
caelo fidelis). Natomiast Symmachus (potem również Teo-

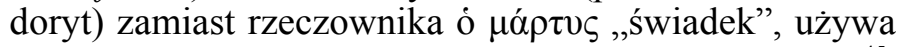
urzeczownikowionego imiesłowu ó $\delta 1 \alpha \mu \alpha \rho \tau v \rho o ́ \mu \varepsilon v o \varsigma^{45}$. וסהיד Sens pozostaje ten sam. Targum thumaczy dosłownie a świadek w chmurze [jest] wierny”, dodając na końcu לעלמין ,na zawsze”. Wersje antyczne thumaczą zatem dosłownie TM, zamieniając jedynie ,chmurę" na „niebo". Ponadto sugerują lekturę przymiotnika ,wierny” w sensie predykatywnym (,,świadek jest wierny"), a nie atrybutywnym (,wierny świadek") ${ }^{46}$.

${ }^{44}$ Por. De Rossi, Variae lectiones, III, 60.

45 Field, Origenis hexaplorum, II, 244. Tego samego czasownika LXX używa na określenie świadectwa Boga przeciw swojemu ludowi, por. Ps 50,7.

${ }^{46}$ D.M. Stec (The Targum of Psalms, 169) tłumaczy jednak ,,a faithful witness in the sky". 


\subsection{Próby zmiany tekstu}

Pomimo zgodności manuskryptów hebrajskich i wersji antycznych, nie brakło prób korekty tekstu, zmierzających

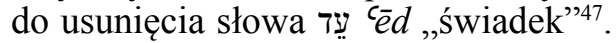

Duhm uważa, że skoro Ps 89 nawiązuje do $2 \mathrm{Sm} 7$, to również w. $38 \mathrm{~b}$ należy czytać w tym kontekście. Bóg nie może więc być świadkiem, bo jest kontrahentem. Nie można również czytać zdania ,świadek w niebie jest wierny”, ale „, jak długo niebo jeszcze jest, jest on (tron) trwały". To jednak wymaga zmiany tekstu z ועד בשקח na . ובעוד השחק

Podechard twierdzi, że ,świadek" nie pasuje do kontekstu. Gdyby chodziło o świadka, gramatyka sugerowałaby, że może nim być księżyc albo tęcza, o których jednak nie myśli się w tym fragmencie. Dlatego proponuje zmianę

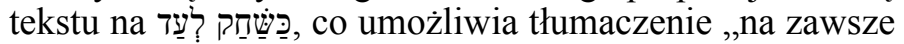
będzie on (tron) trwały jak niebo"49.

Lipiński proponuje usunięcie waw z וٕעֵ , co pozwala mu thumaczyć: ,jak księżyc, będzie trwał wiecznie, utrwalony w niebie na zawsze ${ }^{50}$. Clifford proponuje zmienić wokalizację דעו i czytać słowo jako część występującej

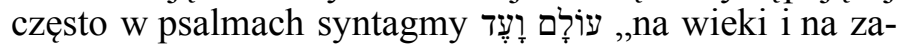
wsze" (por. Ps 10,$16 ; 21,5 ; 45,7 ; 48,15 ; 52,10 ; 104,5)^{51}$.

Za korektą tekstu usuwającą świadka w Ps 89,38 poszły również niektóre thumaczenia. Tak np. Kraus (,wie der Mond soll er ewig dauern und, 'solange es Wolken gibt', währen”52); Lancellotti (,,come la luna sarà stabile per sempre, rimarrà immutabile finché durerà il cielo" ${ }^{53}$ );

${ }^{47}$ Por. Mullen, ,The Divine Witness and the Davidic Royal Grant. Ps 89:37-38”, 211-213; Chisholm, ,עוּ, 339.

${ }^{48}$ Por. Duhm, Die Psalmen, 223.

${ }^{49}$ Por. E. Podechard, „Notes sur les Psaumes: Psaume LXXXIX”, 19-20. Podobnie Briggs - Briggs, Psalms, II, 269.

${ }^{50}$ Por. Lipiński, Le poème royal, 77-78.

${ }^{51}$ Por. Clifford, „Psalm 89”, 28.

${ }^{52}$ Autor twierdzi, że TM nie pasuje do kontekstu, por. Kraus, Psalmen, II, 781.

${ }^{53}$ Por. Lancellotti, I Salmi, 604. 
Sabourin (,sa desandance sera établie come la lune son siège sera plus stable que les cieux" "54); Revised Standard Version (,like the moon it shall be established for ever; it shall stand firm while the skies endure"); New American Bible (,like the moon it will stand eternal, forever firm like the sky!”) czy Edizione di San Paolo (,come la luna sarà stabile per sempre, rimarrà immutabile finché durerà il cielo") $)^{55}$.

Biorąc pod uwagę zarówno tekst hebrajski, wersje antyczne, jak i temat Ps 89, nie ma podstaw, aby eliminować z tekstu wzmiankę o świadku, obecnym podczas boskiej przysięgi danej Dawidowi i jego potomstwu ${ }^{56}$.

\subsection{Dwuznaczność gramatyczna}

Na poziomie gramatycznym pozostaje niepewność,

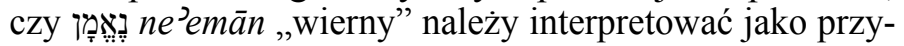
miotnik predykatywny (,,świadek w chmurach jest wierny") czy atrybutywny (,wierny świadek w chmurach").

Zwolennikami drugiej opcji jest większość współczesnych tłumaczeń, jak np. La Sacra Bibbia della Conferenza Episcopale Italiana (,testimone fedele”), Einheitsübersetzung (,der verläßliche Zeuge”), Lutherbibel (,,der treue Zeuge”), Bible de Jérusalem (,témoin véridique”), Traduction Oecuménique de la Bible („en témoin fidèle”), The New International Version (,the faithful witness"), New Revised Standard Version, The Jewish Bible (,,an enduring witness”), Biblia Poznańska, Biblia Paulistów (,wierny świadek").

$\mathrm{Za}$ interpretacją predykatywną przemawia bardziej gramatyka hebrajska, która zasadniczo nie rozdziela przymiotnika w funkcji atrybutu od rzeczownika ${ }^{57}$. Być

${ }^{54}$ L. Sabourin, Le livre des Psaumes, 38.

${ }^{55}$ Por. BW 10 (CD-ROM).

${ }^{56}$ Przeciw zmianie tekstu opowiada się większość egzegetów współczesnych. Zob. także argumentację Veijola, „Davidverheissung”, 17-18.

${ }^{57}$ Por. Veijola, „The Witness”, 414; Chisholm, ,עוּד, 339. Tate (Psalms, 414) pisze: "The only grammatically correct translation of $v$ 38b runs: And a witness in the clouds shall be faithful". 
może to względy gramatyczne sprawiły, że w komentarzach do psalmów egzegeci raczej optują za interpretacją predykatywną. Biorąc jednak pod uwagę fakt, że mamy do czynienia $\mathrm{z}$ tekstem poetyckim, lepsze byłoby tłumaczenie otwarte na dwuznaczność: ,a świadek w chmurach wierny".

Z punktu widzenia gramatycznego pozostaje jeszcze użycie עֵ bez rodzajnika. Dla niektórych jest to wystarczający argument przemawiający za tym, że w tekście mowa jest o nieznanym świadku ${ }^{58}$. Jednak biorąc pod uwagę sposób zastosowania rodzajnika w poezji i logiczną przesłankę, że jeśli świadek ma spełniać swoją funkcję, nie może on być osobą nieznaną czy niezidentyfikowanym przedmiotem, trudno wyciągać tak daleko idące wnioski z faktu, że עِ występuje bez rodzajnika.

\subsection{Tęcza}

Według niektórych egzegetów (Ahlström, Eissfeld) rolę świadka w Ps 89,38 odgrywa tęcza ${ }^{59}$. Argumentem byłoby zadanie przypisane tęczy po potopie, również w kontekście przymierza (por. Rdz 9,12-17). O tęczy na obłokach pisze Ez 1,18. W Syr 50,7 do tęczy w chmurach porównany jest arcykapłan Szymon. Tęcza łączy niebo z ziemią, przez co staje się naturalnym wyrażeniem na określenie więzi Boga i człowieka. Tęcza byłaby wymownym świadkiem także dlatego, że w Ps 89 od w. 39 mamy do czynienia z wrogami narodu, a tęcza to również łuk, atrybut walki Boga ze swymi nieprzyjaciółmi (por. Ps 21,13; 77,18).

Przeciwnicy zwracają uwagę na to, że tęcza nie jest nigdzie nazwana świadkiem. W Rdz 9,12-17 służy ona jako ,znak" (אוֹ 'ôt), a nie ,świadectwo"60.

58 Por. Tate, Psalms, 427.

59 Ahlström, Psalm 89, 130; Eissfeld, „Psalm 80 und Psalm 89”, 2.

${ }^{60}$ Por. Tate, Psalms, 426; Chisholm, ,עוּד, III, 339. 


\subsection{Księżyc (i słońce)}

Wielu tradycyjnie i zgodnie z wersjami antycznymi za świadka uważa księżyc (Augustyn ${ }^{61}$, Delcor ${ }^{62}$, Steymans ${ }^{63}$, Vesco $^{64}$, Lorenzin ${ }^{65}$, Ravasi ${ }^{66}$, Schokel ${ }^{67}$ ), ewentualnie księżyc i słońce (Raszi ${ }^{68}$, Goldingay ${ }^{69}$, Lipiński ${ }^{70}$, Mullen ${ }^{71}$ ).

$\mathrm{Za}$ tą tezą przemawia kontekst w. 38 i gramatyka. Bóg obiecał, że potomstwo Dawida i jego tron będą trwać przed Nim wiecznie jak słońce (w. 37) i księżyc (w. 38). Ostatnia część obietnicy (,świadek w chmurach jest wierny") byłaby pewnego rodzaju komentarzem do obrazu księżyca (lub księżyca i słońca). Księżyc i słońce są wiecznymi świadkami, chociaż nie zawsze są widoczne. Tak samo z przymierzem Dawidowym. Może wydawać się, że zostało ono zerwane albo że Bóg o nim zapomniał, o czym będą mówić następne wersety, ale to zapomnienie

${ }^{61}$ Augustyn tłumaczy rolę księżyca alegorycznie, jako świadka zmartwychwstania ciał, por. Augustinus, Esposizioni sui Salmi, III, 89.

${ }^{62}$ Por. Delcor, „Les attaches littéraires”, 18.

${ }^{63}$ Steymans, ,Deinen Thron”, 237.

${ }^{64}$ Autor podaje również wersję alternatywną: może chodzić o zasadę ogólną, że świadek jak księżyc jest świadkiem wiernym, por. Vesco, Le psautier de David, 817.

${ }^{65}$ Por. Lorenzin, I Salmi, 349.

${ }^{66}$ Por. Ravasi, Il libro dei Salmi, II, 856.

${ }^{67}$ Por. Alonso Schökel - Carniti, I Salmi, II, 243. Oprócz księżyca, jako kandydatów na świadka autor widzi także potomstwo Dawida oraz tron.

${ }^{68}$ Por. Feuer, Tehillim, 1114-1115. Raszi podpiera się tekstem z Jr 33,20: „To mówi Pan: Jeżeli możecie złamać moje przymierze $\mathrm{z}$ dniem i moje przymierze $\mathrm{z}$ nocą, tak że nie nastąpi ani dzień, ani noc w swoim właściwym czasie, to może być także zerwane moje przymierze z moim sługą Dawidem, by nie miał syna zasiadającego jako król na jego tronie, i z moimi sługami kapłanami-lewitami. Jak niezliczone są zastępy niebieskie, niezmierzony piasek morski, tak samo pomnożę potomstwo sługi mojego, Dawida, i moich sług, lewitów".

${ }^{69}$ Por. Goldingay, Psalms, II, 683-684.

${ }^{70}$ Por. Lipiński, Le poème royal, 77-78.

${ }^{71}$ Por. Mullen, „The Divine Witness”, 207-218. 
jest tylko pozorem, jak pozorem jest nieistnienie słońca lub księżyca $\mathrm{z}$ powodu czasowego zachmurzenia ${ }^{72}$.

Kolejnym argumentem ,za" jest fakt, że w tradycji biblijnej siły naturalne (niebo, ziemia, góry) mogą odgrywać rolę świadków (por. Pwt 32,1-2; Iz 1,2-10; Jr 2,12; Mi 6,1-12). Tę samą funkcję w Ps 89 odgrywałoby słońce i księżyc.

Kolejnym argumentem są teksty pozabiblijne (asyryjskie, akadyjskie, fenickie, hetyckie, nawet traktat Hannibala z Filipem Macedońskim), w których wzywa się często księżyc na świadka ${ }^{73}$.

Jedynym sensownym argumentem przeciw tej hipotezie jest fakt, że ani księżyc, ani słońce nie są nazywane w Biblii świadkami, chociaż występują relatywnie często nawet w Księdze Psalmów (104,19; 121,6; 136,9; 148,3) i nawet w kontekście wiecznego panowania Dawida i jego potomstwa (por. Ps 72,5$)^{74}$.

\subsection{Tron Dawida}

Mosca jest jednym z nielicznych biblistów, według których to tron Dawida jest świadkiem w Ps $89,38^{75}$. Argumentem miałby być kontekst (w w. 37 mówi się o tronie); rola tronu jako świadka (skoro kamień, ołtarz, pieśń może być świadkiem, to funkcję tę może również pełnić tron) ${ }^{76}$; nazywanie tronu ,wiernym w chmurach” (paralele

${ }^{72}$ H.U. Steymans („Deinen Thron”, 237) w tym kontekście mówi o niektórych listach asyryjskich, które zawierają użalanie się, że księżyc nie jest widoczny.

${ }^{73}$ Por. Delcor, „Les attaches littéraires”, 18; Lipiński, Le poème royal, 77-78; Mullen, „,The Divine Witness”, 210-214; Steymans, „Deinen Thron", 237.

${ }^{74}$ M.E. Tate (Psalms, 427) twierdzi, że takie rozwiązanie jest niepotrzebną komplikacją i tak trudnego problemu.

${ }^{75}$ Por. Mosca, „Once Again”, 27-37, zwłaszcza 30: „There is one obvious, though too often overlooked, candidate for the role of witness: the Davidic throne itself".

${ }^{76}$ P.G. Mosca („Onca again”, 32) jednak przyznaje sam, że nigdzie w TM tron nie odgrywa roli świadka. 
pozabiblijne mówią o boskim charakterze królewskiego tronu i jego obecności w chmurach).

Słabością tej hipotezy jest nie tylko brak biblijnych tekstów mówiących o tronie jako świadku. Równie dziwnie w tym kontekście brzmiałyby słowa psalmisty o wywróceniu tronu (w. 45). Czyli najpierw Bóg powołuje na wiecznego świadka tron w niebie, a potem go zrzuca na ziemię? ${ }^{77}$

\subsection{Jahwe}

Pewna grupa egzegetów, której najbardziej reprezentatywną postacią jest Veijola, uważa, że w Ps 89,38 Bóg sam siebie wzywa na świadka ${ }^{78}$.

Zwolennicy przywołują paralele biblijne, zwłaszcza Hi 16,19: „Teraz mój Świadek jest w niebie" Jr 42,5: „Bóg nam świadkiem wiernym i prawdomównym". Bóg jest świadkiem również w Ps 50,7; 81,9; Mi 1,2; Ml 3,5. Bóg nazwany jest Bogiem wiernym w Pwt 7,9. Natomiast o Jego zamieszkaniu w chmurach mówi ten sam Ps 89 w w. 7: „Bo któż na obłokach będzie równy Panu, któż wśród synów Bożych będzie do Pana podobny?"80.

Za Bogiem jako świadkiem przemawiałyby też teksty pozabiblijne. Veijola podaje przykłady tekstów hetyckich, w których obłok spełnia funkcję boskiego świadka ${ }^{81}$.

${ }^{77}$ Por. Tate, Psalms, 425.

${ }^{78}$ Por. Delitzsch, Psalms, III, 41-42; Veijola, Verheissung in der Krise, 17-22; Veijola „Davidverheissung”, 17-18; Veijola „The Witness", 413-417; van Leeuwen, „עִ 'èd”, 842; Hossfeld - Zenger, Psalmen 51-100, 595. Tak interpretuje również Euzebiusz z Cezarei i Cyryl Aleksandryjski, por. Eusebius Caesariensis, Commento ai Salmi, II, 220; Nesmy, I Padri, 466.

${ }^{79}$ Delitzsch (Psalms, III, 41) twierdzi, że podobnie jak Ps 88, tak również i Ps 89 należy interpretować w kluczu Księgi Hioba.

${ }^{80}$ Zob. także Pwt 33,26; $2 \mathrm{Sm}$ 22,12; Ps 18,12; 57,11; 68,35.

${ }^{81}$ Por. Veijola, „The Witness”, 415; Veijola, „Davidverheissung", 19. 
Warto ponadto zwrócić uwagę, że Bóg jest pierwszoplanową postacią przebywającą w chmurach. Jedyną, kiedy TM używa słow שِ šahaq (tak jak w Ps 89,38),

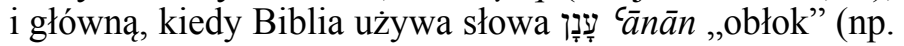
Wj 19,9; Pwt 31,15; Lm 3,44). W obłoku może przebywać także Mojżesz (por. Wj 24,18; 33,9), a na obłokach może znajdować się również tęcza (por. Rdz 9,13-16).

Jedynym i najpoważniejszym zarzutem przeciw identyfikacji świadka z Bogiem jest kwestionowanie tego, że jakoby Bóg mógł wzywać na świadka samego siebie ${ }^{82}$. Jednak pozorna nielogiczność faktu, że Bóg jest dawcą przymierza i jego świadkiem, nie jest całkiem nie do obrony. W Joz 24,24 zawierający przymierze są jednocześnie świadkami, a w Hi 16,19-21 Bóg jest i świadkiem, i tym, do którego można się zwracać, by rozwiązać spór między Bogiem a człowiekiem. Podwójna funkcja Boga, partnera i gwaranta przymierza, byłaby naturalną konsekwencją przeniesienia modelu traktatów politycznych na płaszczyznę teologiczną ${ }^{83}$.

\subsection{Interpretacja mesjańska}

Grzegorz Wielki i Hieronim twierdzą, że świadkiem wiernym w niebie jest Chrystus ${ }^{84}$. Na pierwszy rzut oka wygląda to jak interpretacja alegoryczna, zastanówmy się jednak, czy istnieją przesłanki, by Ps 89,38 czytać w kluczu proroctwa, a w świadku wiernym widzieć Mesjasza.

${ }^{82}$ E.T. Mullen („The Divine Witness”, 216) pisze: „Since Yahweh constituted a party to the treaty, only the forces of nature could be invoked as witnesses, not the deity himself'. Jeszcze mocniej wyraża się M.E. Tate (Psalms, 426): „This thesis too seems highly improbable. None of the passages in which Yahweh acts a witness involve him as a witness to his own oath; he is a witness of covenant agreements and oaths taken by others. In Ps 89 Yahweh affirms that there is a witness to the commitments he has taken, and the witness can hardly be himself, unless he is playing word games".

${ }^{83}$ Por. Veijola, „Davidverheissung”, 19.

${ }^{84}$ Por. Nesmy, I Padri, 466. Por. PL 75, 1030. 
W Ps 89 jest mowa o mesjaszu rozumianym jako poniżony Dawid lub jego potomek (por. w. 39.52). Podobieństwo Ps 89,36-38 do mesjańskiego proroctwa Natana 2 Sm 7,1-16 (zwłaszcza ww. 14-16) (5) $^{85}$ wkazuje na to, że tekst mówiący o świadku może być czytany jako proroctwo mesjańskie. Prorocki charakter Ps 89,38 wynika również z faktu, że psalmista wkłada w usta Boga cały fragment Ps 89,20-38, cytując je jako słowa, które Bóg mówił „w widzeniu do swoich świętych"86. Według proroctwa Daniela na obłokach przybywa jakby Syn Człowieczy (por. Dn 7,13-14). Wizja ta rozumiana była przez Jezusa jako odnosząca się do niego. W czasie procesu na pytanie arcykapłana „Poprzysięgam Cię na Boga żywego, powiedz nam: Czy Ty jesteś Mesjasz, Syn Boży?” (Mt 26,63), Jezus odpowiada: „Tak, Ja Nim jestem. Ale powiadam wam: Odtąd ujrzycie Syna Człowieczego, siedzącego po prawicy Wszechmocnego i nadchodzącego na obłokach niebieskich" (Mt 26,64). Reakcja Wysokiej Rady jest dowodem na to, że tekst z Księgi Daniela był interpretowany w czasach Jezusa w kluczu mesjańskim. Również Apokalipsa mówi o nim jako o Synu Człowieczym, który przybywa i zasiada na obłokach $($ Ap 1,$7 ; 14,14)$. Ta sama Apokalipsa nazywa Chrystusa świadkiem i wier-

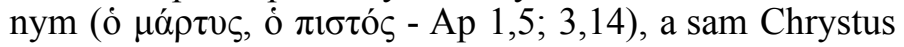
wielokrotnie wyznaje, że przyszedł na ten świat, aby dać świadectwo (por. J 5,36; 8,14.18; 18,37). Ponadto w Ewangelii nie trudno znaleźć teksty łącze Jezusa z Dawidem, począwszy od pierwszego zdania pierwszej Ewangelii: „Rodowód Jezusa Chrystusa, syna Dawida” (Mt 1,1) ${ }^{87}$.

Interpretując postać świadka w Ps 89 w kluczu mesjańskim i prorockim, otrzymujemy następujący sens: Bóg zawarł przymierze z Dawidem i jego potomstwem. Ono będzie trwać wiecznie. Paradoksalnie jednak teraz Pomazaniec Pański cierpi i jest odrzucony. Mówi o tym

${ }^{85}$ Por. Duhm, Die Psalmen, 223; Lipiński, Le poème royal, 77-78.

${ }^{86}$ Słowo ,widzenie” (חָזוֹ) jest typowym określeniem proroctwa, por. Iz 1,1; Ab 1,1; Na 1,1; Oz 2,11.

${ }^{87}$ Zob. także Mt 9,27; 12,23; 15,22; 20,30-31; 21,9.15; 22,42-45. 
koniec III Księgi Psałterza (Ps 89,39-52), tak jakby redaktor chciał przekazać, że doświadczeniem obecnego czasu jest dramat pozornej niewierności Boga. Doświadczenia te nie mogą jednak przekreślić tego, co Bóg postanowił. Świadkiem Bożej wierności jest Mesjasz, na razie ukryty w obłokach, ale przyjdzie, gdy nastąpi pełnia czasów. W tym świetle zrozumiałe jest także, dlaczego Ps 89 przedstawia świadka w sposób niedookreślony. Każde proroctwo będzie dookreślone bowiem dopiero wtedy, kiedy się wypełni. Na poziomie psalmisty świadkiem Boga jest Mesjasz, potomek Dawida ${ }^{88}$. Na poziomie Nowego Testamentu to Chrystus, Nowy Dawid, Mesjasz, a zarazem Syn Boży. Interpretacja mesjańska świadka w Ps 89,38 nie jest bardziej niedorzeczna niż widzenie świadka w tęczy, księżycu czy słońcu. Co więcej, pozwala lepiej zrozumieć, dlaczego z punktu widzenia paralel tekstualnych wydawało się najbardziej naturalnym, że wiernym świadkiem powinien być sam Bóg.

\section{Przeklad terminu פִּרוּת}

Trzecią szczegółową kwestią związaną ze świadectwem w psalmach, którą warto podjąć, a która nie była zbytnio obecna w analizach egzegetów, jest sprawa thumaczenia עֵּוּר w najdłuższym psalmie 23 razy $^{89}$. Pytanie, które narzuca się naturalnie, brzmi: czy mamy do czynienia z terminem technicznym, który należy tłumaczyć zawsze tak samo,

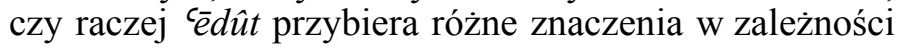
od kontekstu.

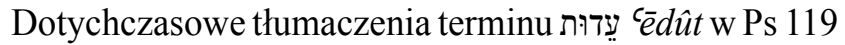
można podzielić na następujące rodzaje:

${ }^{88}$ Por. analizę Eatona, który przekonuje, że świadkiem w Ps 89,38 jest król, por. Eaton, „,The King”, 35-36.

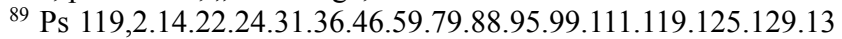
8.144.146.152.157.167.168. 
a) Tłumaczenie $c^{c} d \hat{u} t$ zawsze tym samym słowem i zawsze w l. mn.: LXX ( $\mu \alpha \rho \tau v ́ \rho ı \alpha)$, Allen (,terms”), The Jewish Bible, New Revised Standard Version, Brueggeman-Bellinger (,decrees”), New International Version (,statues"), New American Bible (,tesimonies”), Edizione di San Paolo, Lancellotti (,voleri”).

b) Tłumaczenie 'édût zawsze tym samym słowem, ale nie zawsze w 1. mn.: Delitzsch (,Zeugnisse”, „Zeugniss” w w. 88), Seybold (,Verordnungen”, „Verordnung” w. 88) $)^{90}$, Zenger (,Zeugnisse”, „Zeugniss” w. 88.111); Goldingay („declarations”, „declaration” w. 88), Bibbia della Conferenza Episcopale Italiana, Ravasi (,,insegnamenti”, ,insegnamento" w. 88), Sabourin (,ordonnances”, „ordonnance” w. 88); Vesco („témoignages”, „témoignage” w. 88).

c) Tłumaczenie ‘èdût zawsze tym samym słowem i zawsze w 1. poj.: Bible de Jérusalem („témoignage”).

d) Tłumaczenie 'ēdût zawsze w 1. mn. i zasadniczo jednym słowem: Wulgata (testimonia, mandata w. 146); Luter (,Mahnungen”, ,Zeugnisse” w. 46); Castellino (,testimonianze”, „ordini” w. 168).

e) Tłumaczenie 'édut zasadniczo jednym słowem, ale z niektórymi wyjątkami również co do liczby: Kraus (,Zeugnisse”, „Zegunis” w w. 88, „Weisungen” w w. 7991), Dahood (,stipulations", „stipulation” w. 88, ,precepts” w. 31), Einheitsübersetzung (,Vorschriften”, „Gebote” w. 46, „was du vorschreibst” w. 22, ,was du gebietest" w w. 95.119.125.167), Alonso Schökel (,precetti”, „,istruzione” w w. 88), Lorenzin (,,insegnamenti”, ,,insegnamento" w w. 88, ,comandamenti” w w. 59), Jacquet (,témoignages”, „préceptes” w ww. 22.152.168; „volontés” w. 138) ${ }^{92}$, Traduction Oecuménique de la Bible

${ }^{90}$ K. Seybold (Die Psalmen, 471) podaje w nocie, że 11QPsa i LXX mają l. mn.

${ }^{91}$ H.-J. Kraus (Psalmen, II, 995) thumaczy, że wybiera lekcję Qere.

92 Autor wyjania odstępstwa od thumaczenia „témoignages" tym, że słowo to znajduje się już w odpowiedniej części akrostychu. W w. 168 zmiana podyktowana jest zakładanym błędem dittografii, por. Jacquet, Les Psaumes, III, 352, 380-381, 384. 
(„exigences”, „,e que ta bouche édicte” w. 88), Biblia Tysiaclecia („,napomnienia”, „upomnienia” w. 2.14.152.157 „rozkazy” w. 46, „postanowienia” w. 138), Biblia Paulistów (,pouczenia”, ,postanowienia” w. 138), Biblia Poznańska (,rozkazy”, „nakazy” w. 2.14.79.167.168, „ustawy” w. 31.36.99.119.129.138.144), Biblia Warszawska (,świadectwa”, „ustawy” w. 14.24.36, „przykazania” w. 138.152.157, ,napomnienia” w w. 2), Biblia Warszawsko-Praska (,nakazy”, „,co nakazujesz” w. 22.95.125, „, co każesz” w. 88, „rozkazy” w. 168, „pouczenia” w. 14.138, „upomnienia” w. 36, ,przykazania” w. 129, „prawo” w. 111, „będę świadczył” w. 46).

$\mathrm{Z}$ tłumaczeń nasuwają się następujące wnioski:

a) Tłumaczenia wahają się od tych, które 'ēdût tłumaczą zawsze tym samym słowem i w tej samej liczbie, do tych, które tłumaczą je różnymi słowami, w różnych liczbach, a nawet używając zdań podrzędnych.

b) Jeśli chodzi liczbę, to 'êdût raczej thumaczy się w 1. mn. Szczególnie zauważany jest w. 88 , gdzie TM ma 1. poj.

c) Jeśli chodzi o konsekwencję, to 'édût raczej oddawane jest jednym słowem. Wyjątki nie podlegają regule i dotyczą wielu różnych wersetów.

d) Jeśli chodzi o rozumienie pojęcia to 'éêut interpretowane jest jako świadectwo, nauczanie, napomnienie i ustawa (dekret).

Z powyższego zestawienia tłumaczeń widać, że dla większość autorów עִ צִ cedût ani nie jest terminem technicznym, ani nie można ustalić jego zasadniczego znaczenia.

Większość egzegetów zajmujących się Ps 119 stwier-

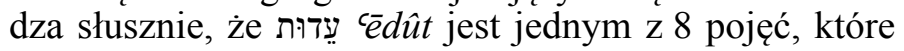
autor używa konsekwentnie na określenie tory, względnie słowa Bożego ${ }^{93}$.

${ }^{93}$ Por. Kraus, Psalmen, II, 966; Hossfeld - Zenger, Psalmen 101$150,352-354$. 
Termin ten w Ps 119 jest jednym z pięciu terminów sądowniczych, a jednym $\mathrm{z}$ trzech, które ma wyłącznie prawne znaczenie ${ }^{94}$. To wskazuje, że świadectwo nie jest sprawą prywatną, ale że chodzi o porządek życiowy i zbawczy społeczeństwa i świata ${ }^{95}$.

Bardziej szczegółowe analizy egzegetów prowadzą do rozbieżnych wyników. Choon-Leong twierdzi, że podstawowe znaczenie słowa 'édût to „umowa”, natomiast w źródle kapłańskim nabiera ono znaczenia ,przymierze" ${ }^{\prime 96}$. Nie zgadza się z nim Couroyer, twierdząc, że słowu temu bliżej jest do znaczenia ,nauczanie” niż do traktatu ${ }^{97}$.

Jeszcze inaczej widzi problem Volkwein, wg którego עִ צִדוּת dectwo" (lub od czasownika עוד עדíwiadczyć"), albo od aramejskiego עדי,traktat, warunki traktatu”. W Ps 119, który jest deutoronomistyczną wizją prawa, עִדּוּר cédût powinno się tłumaczyć przez „,postanowienia przymierza” (Bundesbestimmungen), albo - jeśli kontekst na to nie pozwala - bardziej ogólnie przez „prawo” (Gesetz) ${ }^{98}$. Taką opinię podziela również Kent ${ }^{99}$.

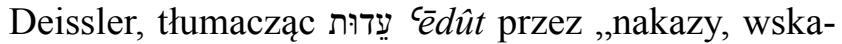
zówki” (Weisungen), mówi o pewnej ewolucji pojęcia. Ewolucja ta nastąpiła ze świadectwa do prawa poprzez znaki świadczące, upomnienia i jest ona zrozumiała w społeczności, w której Bóg jest zarazem dawcą prawa, jak i jego głównym świadkiem ${ }^{100}$.

Słowo עִדּוּת cedut w Ps 119 powinno się thumaczyć zawsze jako „świadectwa” (ewentualnie „świadectwo” w w. 88). Słowo to w języku polskim należy do języka prawnego, a zarazem używane jest w kontekście Bożego objawienia, prawdy, którą należy głosić innym. To podwójne

${ }^{94}$ Por. Hossfeld - Zenger, Psalmen 101-150, 354; Soll, Psalm 119, 45.

${ }^{95}$ Por. Hossfeld - Zenger, Psalmen 101-150, 354.

${ }^{96}$ Por. Choon-Leong, ,The Designation of the Ark”, 192-193.

${ }^{97}$ Por. Couroyer, „Édût”, 321-331.

${ }^{98}$ Por. Volkwein, „Masoretisches 'edut, 'edwot, 'edot”, 39-40.

${ }^{99}$ Por. Kent, Torah as Teacher, 111-112.

${ }^{100}$ Por. Deissler, Psalm 119 (118), 78. 
zastosowanie słowa przybliża nas do zakresu znaczenio-

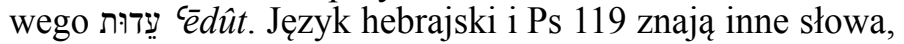
które przekazują bardziej idee prawa, umowy czy nauczania. Jeśli zatem autor zdecydował się na wielokrotne uży-

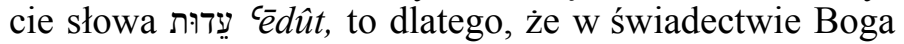
widział manifestację i potwierdzenie wychwalanej Tory. Może trudnością językową jest fakt, że w języku polskim częściej mówi się, o tym, że Bóg jest świadkiem, albo że Bóg świadczy, niż o Jego świadectwach. Nie można jednak zapominać o kształtującej myślenie funkcji tłumaczeń.

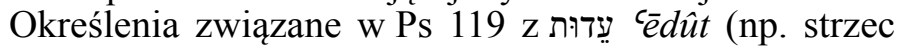
świadectwa, mówić o nim, cieszyć się nim) nie wydają się brzmieć sztucznie w języku polskim ${ }^{101}$, a mogą kształtować przekonanie, że Bóg nie tylko dał ludziom zbawcze objawienie i prawo, ale także potwierdza je licznymi świadectwami, których warto strzec, cieszyć się nimi i mówić o nich nawet wobec królów (por. Ps 119,46).

\section{Podsumowanie}

Analiza trzech intrygujących kwestii świadectwa związanego ze słowem עyוּ w Psalmach, to jest obecności

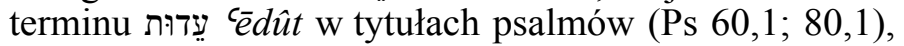
rozumienia, kim jest świadek w Ps 89,38 , oraz tłumaczenia terminu עִ עִדוּית tematyzować dotychczasowe badania egzegetyczne, ale zaproponować nowe rozwiązania lub nowe argumenty dla podejmowanych już rozwiązań.

Analiza terminu צִּדוּר wadzi do wniosku, iż termin ten należy interpretować jako niezależną część tytułu i tłumaczyć jako ,świadectwo”. Obok różnorakich odpowiedzi na pytanie, kim jest świadek w Ps 89,38 (tęcza, słońce, księżyc, tron, Bóg), została zaproponowana nowa interpretacja mesjańska. Ponadto po-

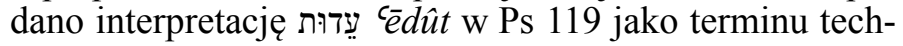
nicznego i oddawania go zawsze terminem „świadectwo”.

${ }^{101}$ Por. pkt 1c w tym artykule. 


\section{Bibliografia}

Ahlström G.W., Psalm 89. Eine Liturgie aus dem Ritual des leidenden Königs (Lund 1959).

Alonso Schökel L. - Carniti C., I Salmi (Roma 1992).

Augustinus, Esposizioni sui Salmi (red. T. Mariucci - V. Tarulli)

(Nuova Biblioteca Agostiniana 27; Roma 1976).

Boese H.H., Anonymi Glossa Psalmorum ex traditione senio-

rum. I. Praefatio und Psalmen 1-100 (VL 22 I; Freiburg im Breisgau 1992).

Briggs C.-A. - Briggs E.G., A Critical and Exegetical Commentary on The Book of Psalms (ICC; Edinburgh 1906).

Choon-Leong S. „The Designation of the Ark in Priestly Theology", Hebrew Annual Review 8 (1984) 185-198.

Clifford R.J., „Psalm 89. A Lament over the Davidic Ruler's Continued Failure", Harvard Theological Review 73 (1980) 35-47.

Clines D.J.A. (red.), The Dictionary of Classical Hebrew (Sheffield 1993-2011).

Couroyer B., „Édût: Stipulation de traité ou enseignement?”, Revue Biblique 95 (1988) 321-331.

Chisholm R.B., „עוּד,", New International Dictionary of Old Testament Theology and Exegesis (red. W.A. VanGemeren) (Grand Rapids 1997) III, 335-340.

Deissler A., Psalm 119 (118) und seine Theologie. Ein Beitrag zur Erforschung der anthologischen Stilgattung im Alten Testament (München 1955).

Delcor M., „Les attaches littéraires, l’origine et la signification de l'expression biblique "prendre à témoin le ciel et la terre»", Vetus Testamentum 16 (1966) 8-25.

Delekat L., „Probleme der Psalmenüberschriften”, Zeitschrift für Alttestamentliche Wissenschaft 76 (1964) 280-297.

Delitzsch F., Psalms (Commentary on the Old Testament in Ten Volumes. Volume V; Grand Rapids 1980).

Duhm B., Die Psalmen (Tübingen 1899).

De Rossi J.B., Variae lectiones Veteris Testamenti ex immensa Mss. editorumq. codicum congerie haustae et ad samar. textum, ad vetustiss. versiones, ad accuratiores sacrae criticae fontes ac leges examinatae (Parmae 1787). 
De Sainte-Marie H., Sancti Hieronymi psalterium iuxta Hebraeos. Édition critique (CBLa 11; Roma 1954).

Eaton J. H., ,The King as God's Witness”, Annual of the Swedish Theological Institute 7 (1968-1969) 25-40.

Eerdmans B.D., The Hebrew Book of Psalms (OTS 4; Leiden 1947).

Eissfeld O., „Psalm 80 und Psalm 89”, Die Welt des Orients 3 (1964) 27-31.

Eusebius Caesariensis, Commento ai Salmi (red. M.B. Artioli) (CTePa 176; Roma 2004).

Even-Shoshan A., A New Concordance of the Bible (Jerusalem 1989).

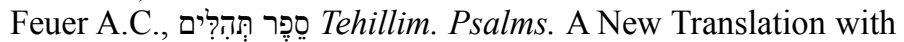
a Commentary Anthologized from Talmudic, Midrashic, and Rabbinic Sources (The Artscroll Tanach Series; New York 2004).

Field F., Origenis hexaplorum quae supersunt sive Veterum Interpretum Graecorum in totum Vetus Testamentum Fragmenta. II. Jobus - Malachias, Auctarium et Indices (Oxonii 1875).

Goldingay J., Psalms. II. Psalms 42-89 (Baker Commentary on the Old Testament Wisdom and Psalms; Grand Rapids 2007).

Gunkel H., Die Psalmen (HK II.2.2; Göttingen 1926).

Hirsch S.R., The Psalms (Jerusalem - New York 1997).

Hossfeld F.-L. - Zenger E., Psalmen 51-100 (HThKAT; Freiburg im Breisgau 2000).

Hossfeld F.-L. - Zenger E., Psalmen 101-150 (HThKAT; Freiburg im Breisgau 2008).

Jacquet L., Les Psaumes et le coeur de l'Homme. Étude textuelle, littéraire et doctrinal (Gembloux 1978).

Kent A., Torah as Teacher. The Exemplary Torah Student in

Psalm 119 (Leiden - Boston 2010).

Kraus H.-J., Psalmen (BK 15/1-2; Neukirchen - Vluyn ${ }^{5} 1978$ ). Lancellotti A., I Salmi. Versione, introduzione e note (NVB 18/C; Roma 1984).

Leeuwen C. van, , עֵד 'e d', Theological Lexicon of the Old Testament (red. E. Jenni - C. Westermann) (Peabody 1997) 838-846. 
Lipiński E., Le poème royal du Psaume LXXXIX 1-5.20-38 (CRB 6; Paris 1967).

Lisowski G., Konkordanz zum hebräischen Alten Testament (Stuttgart ${ }^{2}$ 1981).

Lorenzin T., I Salmi. Nuova versione, introduzione e commento

(I Libri Biblici. Primo Testamento 14; Milano 2000).

Mandelkern S., Veteris Testamenti concordantiae hebraicae atque chaldaicae (Tel Awiw 1977).

Mosca P.G., „Once Again the Heavenly Witness of Ps 89:38”, Journal of Biblical Literature 105 (1986) 27-37.

Mowinckel S., Psalmenstudien. IV. Die Technischen Termini in den Psalmenüberschriften (Kristiania 1923).

Mullen E.T., „The Divine Witness and the Davidic Royal Grant. Ps 89:37-38", Journal of Biblical Literature 102 (1983) 207218.

Nesmy J.-C. (red.), I Padri commentano il Salterio della tradizione (Torino 1983).

Neubauer A., „The Authorship and the Titles of the Psalms according to Early Jewish Authorities", Essays Chiefly in Biblical and Patristic Criticism (red. zbiorowa) (Studia Biblica et Ecclesiastica 2; Oxford 1889) 1-58.

Podechard E., „Notes sur les Psaumes: Psaume LXXXIX”, Revue Biblique 34 (1925) 5-31.

Rahlfs A. (red.), Psalmi cum Odis (Vetus Testamentum Graecum. Auctoritate Academiae Scientiarum Gottingensis editum 10; Göttingen 1979).

Ravasi G., Il libro dei Salmi I-III. Commento e attualizzazione (Bologna ${ }^{9} 2002$ ).

Sabourin L., Le livre des Psaumes, traduit et interprété (Recherches Nouvelle Série 18; Montréal - Paris 1988).

Seybold K., Die Psalmen (HAT 1/15; Tübingen 1996).

Simian-Yofre H., עוד 'wd", Grande lessico dell'Antico Testamento (red. G.J. Botterweck - H. Ringgren) (Brescia 2006) VI, 483-507.

Soll W., Psalm 119. Matrix, Form and Setting (Washington 1991).

Staerk W., „Zur Kritik Psalmenüberschriften”, Zeitschrift für alttestamentliche Wissenschaft 12 (1892) 91-151. 
Stec D.M., The Targum of Psalms. Translated, with a Critical Introduction, Apparatus, and Notes (The Aramaic Bible 16; Collegeville 2004).

Steymans H.U., „Deinen Thron habe ich unter den großen Himmeln festgemacht. Die formgeschichtliche Nähe von Ps 89,4-5.20-38 zu Texten vom neuassyrischen Hof”, „,Mein Sohn bist du” (Ps 2,7) (red. O. Eckart) (Stuttgart 2002) 184-251.

Tate M.E., Psalms. 51-100 (WBC 20; Dallas 1990).

Veijola T., Verheissung in der Krise. Studien zur Literatur und Theologie der Exilzeit anhand des 89. Psalms (Helsinki 1982).

Veijola T., „Davidverheissung und Staatsvertrag. Beobachtungen zum Einfluss altorientalischer Staatsverträge auf die biblische Sprache am Beispiel von Psalm 89", Zeitschrift für alttestamentliche Wissenschaft 95 (1983) 9-31.

Veijola T., „The Witness in the Clouds. Ps 89:38”, Journal of Biblical Literature 107 (1988) 413-417.

Vesco J.-L., Le psautier de David traduit et commenté (LeDiv 210; Paris 2006).

Volkwein B., „Masoretisches 'edut, 'edwot, 'edot - «Zeugnis» oder «Bundesbestimmungen»?", Biblische Zeitschrift 13 (1969) 18-40.

William J., The Title of the Psalms. Their Nature and Meaning Explained (London 1907).

Yalkut Me'am Lo'ez, Torah Anthology. The Book of Tehillim (New York 1989). 
Ks. Wojciech Węrrzyniak

Św. Anny 11/11

31-008 Kraków

wojciech.wegrzyniak@gmail.com

Ks. WoJCIECh WĘGRZYNIAK, kapłan archidiecezji krakowskiej, adiunkt Katedry Egzegezy Starego Testamentu Uniwersytetu Papieskiego Jana Pawła II w Krakowie, licencjat nauk biblijnych rzymskiego Biblicum (2004), doktor nauk biblijnych i archeologii Studium Biblicum Franciscanum w Jerozolimie (2010) na podstawie pracy Lo stolto ateo. Studio dei Salmi 14 e 53 (Studia Biblica Lublinensia 11; Lublin: Wydawnictwo KUL, 2014), popularyzator wiedzy biblijnej, komentator życia Kościoła, kaznodzieja i rekolekcjonista (www.wegrzyniak.com). 
